\title{
Study on Factors Influencing the TQM Practices and its Consequences
}

\author{
S. Deepika, Dr.S. Anandakumar and Dr.V. Krishnamoorthy
}

\begin{abstract}
The study examines the influence of factors leading to implementation of TQM practices in building industry. The researcher adopted random sampling method for collecting data from the respondents. This study has been conducted from the period of May 2015 to Jan 2016. The study identified 8 important magnitudes of TQM practices. These are Organizational Factors, Communicational Factors, Cultural Factors, Quality Management Factors, Customer Satisfaction Factors, Employee Job Related Factors, Employee Training Related Factors, Management Commitment Factors out of the identified practices the study recognized that there is a significant impact on Communicational Factors, Quality Management Factors, Customer Satisfaction Factors, Employee Training Related Factors, Management Commitment Factors with the Organizational Development. The study conclusion would help the policy makers to the frame appropriate policies concerning TQM.
\end{abstract}

Keywords--- Total Quality Management, Statistical Analysis, Implementation, Magnitudes

\section{INTRODUCTION}

$\mathrm{A}$ LTHOUGH the current competitiveness of the business environment, every company should desires to be successful in achieving quality. This may be achieved through careful planning and good management quality practices for their products and services. This will be imposing to both national markets for economical development of the countries. Construction industries, they are in need of providing high quality products and services to their customers and clients. So therefore, the construction industry is the core of any nation and so it plays an essential role to the growth of country's infrastructure. In addition, the industries faces problems of developing economy, such as low productivity, lack of principles and poor excellence of merchandise and services (Grifa, 2007). Quality association is a necessary element of of construction project management (Tang and Andrew, 2009).

Quality administration essentially is the course of assuring that a good or service continuously meet and need to exceed customer needs and can be generally looked at as a business

S. Deepika, Final Year M.E(Construction Engineering and Management), Kongu Engineering College, Perundurai, TamilNadu, India. E-mail:deepikongu13@gmail.com

Dr.S. Anandakumar, Professor, Department of Civil Engineering, Kongu Engineering College, Perundurai, TamilNadu, India. E-mail:anandkeccivil15@gmail.com

Dr.V. Krishnamoorthy, School of Management Studies, Kongu Engineering College, Perundurai, TamilNadu, India. E-mail:krishnamoorthydd@gmail.com DOI: 10.9756/BIJIEMS.7088 management way that attempts to maximize organizational rewards throughout continuous process up gradation of its products, services, manpower in company, processes improvement, and environment. Ever since it is a management based approach it can be achieved all the way through total involvement and participation of everybody in the association led by the management people (Kasongo \& Moono, 2010). The Total Quality Management is one of the main association approaches, so that can be used to achieve continuous quality improvement of the products. From after that, quality management has emerge through quality examination(QI), to quality control(QC), to quality assurance(QA) then to the current Total quality management (TQM) (Kenya Institute of Management, 2009).A critical winning implementation of TQM factors is connected to monetary and presentation achievement of every association. The benefits and improvements are come in the areas of fewer faults and errors, decreased waste, increased disposal, increased quantity, increased profit, market share, stronger relationships with suppliers increased employee, customer satisfaction, consistency, reduced manufacture time, drop in the quantity of goods damaged in transit, Improvement in customer perceptions of the organization, decrease in costs (Brah et al., 2002; Hansson and Eriksson 2002; Hendricks and Singhal 2001; Kaynak, 2003).

\section{LITERATURE REVIEW}

Various studies has been conducted with regard to the total quality management studies by Ali Mohammad Mosadeghrad (2014) identified the factors that are likely to obstruct TQM implementation enables managers to develop more effective strategies for enhancing the likelihood chances of achieving business quality. An assessment of $54 \mathrm{TQM}$ experiential studies recognized 54 obstacles to victorious TQM implementation. An unproductive TQM wrap up, unsuitable TQM implementation methods and unsuitable surroundings for implementing TQM are the main reasons for TQM breakdown. Managers need to be conscious about and speak to these barriers if the TQM programmes are to have a optimistic impact on organisational presentation.

A learn conducted by Muatafa Maher Altayeb (2014) has exposed that the building industry has been one of the most important for initial infrastructure and financial system of the Palestinian. In this revise the author establish that sensational factors essential for the functioning of TQM at various parts of the project planning, design, and construction in the Gaza strip. The investigation resolute that 7 significant success factors with 38 sub factors out of 8 major factors and 81 sub factors. It was proven that continuous improvement is the most critical factor for the successful implementation of TQM 


\section{in Gaza strip organization.}

This investigate seeks to recognize the specific leadership competencies requisite for implementing (TQM). Anupam Das (2011) elective that the TQM original inscription widely ropes the requirement of management obligation and management for winning TQM implementation, but there is little agreement about the management that are essential to put into practice the specific TQM principles (Gonza 'lez and Guille ' $n$, 2002). The situation of manager to perform as leadership is also essential for the achievement in the TQM initiative (Perles, 2002). Using their official authority, dedicated managers can guide this progression by facilitate the allocation of property and follower those who expand the TQM development. Leadership goes beyond the boundary of formal power. Leaders create a new environment in the organization by their inter-personal relationships and influences that involve others in the change initiative.

The study has exposed the degree of submission of TQM main beliefs and then investigated the association between TQM implementation and labour efficiency in manufacturing companies. The research done by Ross Chapman (2002) .This learns establish that mean labour efficiency capacity for highTQM firms be considerably superior than for low-TQM firms.

The researcher Zakuan et al. (2012) measured teaching as a significant factor that boosts employee's hard work towards development. To him, quality preparation includes humanizing and training of workers at all levels in the association with a meaning of expansion their information on quality issues and programs and as long as them with in sequence about the organization's quality assignment, visualization and general wanted way.

Jaideep Motwani (2001) study states that TQM principles and techniques are now a well-accepted division of approximately every manager's "tool kit" (Dow et al., 1999). The mean of this learn is to identify and understand the critical factors and performance way of TQM. Based on widespread reconsider of regulatory, theoretical, consultant, and empirical creative writing author recognize seven critical factors and more than 45 presentation method of TQM. So the implementation of these factors is worried, TQM will be visualized as building a house. First, putting top management commitment to TQM at the same time as the base or basement. Without a strong foundation, the house will never stand. On one occasion the groundwork is in place, concentration should be given to employee education and empowerment, quality dimension and benchmarking, process organization, and customer participation and contentment. These factors can be viewed as the four pillars of a house.

The researcher Ross Chapman (2002) has identified the degree of appliance of TQM principles and then investigated the association between TQM implementation and labour productivity in manufacturing company. This research also identified the relationship between all the probable fundamentals of TQM and labour productivity throughout functioning. The study establishes that average labour productivity dimensions for high-TQM companies were appreciably higher than for low-TQM firms. So it shows that if the organization has higher level of TQM implementation having higher level of labour productivity, if the organization has lower level of TQM implementation having lower level of labour productivity. The final results of regression analysis and factor analysis demonstrate that there is a linear association between TQM and labour productivity. This connection showed a high positive gradient in organizations with ISO 9000 certification, and significantly lower but still positive gradient in organization without ISO 9000 certification.

\section{PROJECT RESEARCH MOdEL}

This study is approached with the following proposed research model

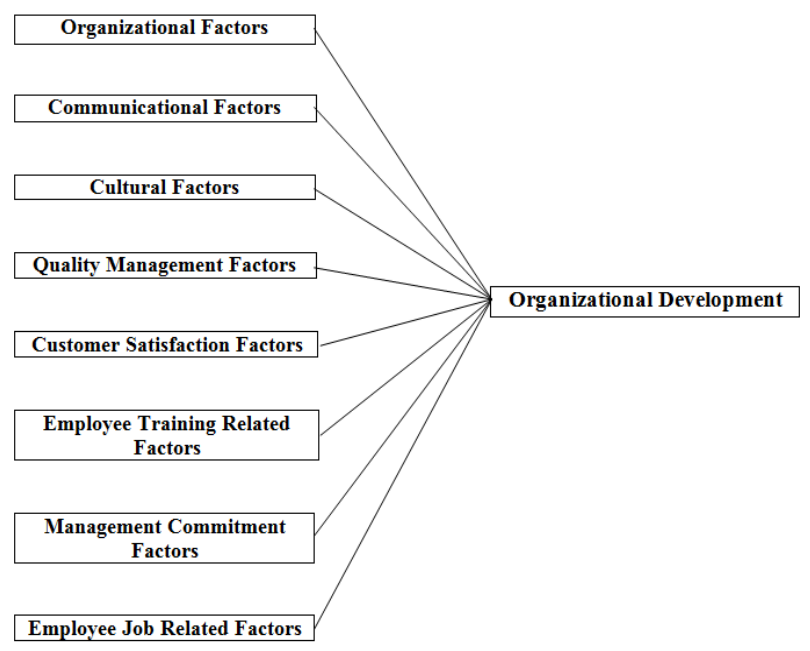

\section{OBJECTIVES OF THE STUDY}

Based on a relevant literature review of TQM practices in construction industries, the research objectives are confined to:

- To discover the various antecedents of TQM practices in building industries.

- To scrutinize the impact of TQM practices in building industries.

\section{Methodology}

The span of the learning is restricted only to the site supervisors, site engineers and Managers of the building projects Tamil Nadu. The researcher used questionnaire system for collecting data from the respondents. The questionnaire contains of three parts. The first part defines demographic profile of the respondents, the second division of the questionnaire consisted questions linked to TQM practices and third component of the questionnaire consists of variables describing the organisational development. This study was conducted for the period of May 2015 to Jan 2016. Before conducting the study, Pilot study was conducted from site engineers, project managers, supervisors. Based on their opinion, a slight modification was made in the questionnaire. Before administering the questionnaire, the content validity of the questionnaire was verified from the committee which consist of experts in the TQM and academicians. 


\section{PROPOSED HYPOTHESIS}

The researcher approached the study with following hypothesis.

Ho1: Organizational dimensions will have no significant impact on Organizational Development.

Ho2: Communicational dimensions will have no significant collision on Organizational Development.

Ho3: Cultural dimensions will have no significant impact on Organizational Development.

Ho4: Quality Management Factors will have no significant impact on Organizational Development.

Ho5: Customer Satisfaction Factors will have no significant impact on Organizational Development.

Ho6: Employee Job allied dimensions will have no significant impact on Organizational Development.

Ho7: Employee Training allied dimensions will boast no significant impact on Organizational Development.

Ho8: Management Commitment dimensions will encompass no significant impact on Organizational Development.

\section{Frame Work of Analysis}

In order to identify the TQM Practices dimensions factor analysis has been administered. Then the factor value was obtained from the acknowledged TQM Practices that was used as self-governing variables for supplementary analysis. The multiple regression was used to find out the impact of TQM Practices dimensions on the Organizational Development.

\section{Instrument Development}

The variables relating to the present study are drawn from the previous works done by (Wesonga bonventure oruma 2014), (Ali Mohammad Mosadeghrad 2014), (Mustafa Maher Altayeb \& Mahmoud Bashir Alhasanat 2014), (Anupam Das, Vinod Kumar and Uma Kumar, 2011), (Jaideep Motwani 2001), (K.Subrahmanya Bhat\&Jagadeesh Rajashekhar 2009). Appropriate modification has been made in the existing questionnaire to suit the requirements of the present study.

\section{Reliability of the Proposed Scale}

The coefficient alpha scores were calculated for assessing reliability of the ATM service quality scale, which are listed in dimension wise in Table: I

Table I: Reliability of the Various TQM Practices Dimensions

\begin{tabular}{|l|l|}
\hline Reliability Statistics \\
\hline Cronbach's Alpha & No of Items \\
\hline .760 & 28 \\
\hline
\end{tabular}

The coefficient alpha value for Organizational Factors, Communicational Factors, Cultural Factors, Quality Management Factors, Customer Satisfaction Factors, Employee Job Related Factors, Employee Training Related Factors, Management Commitment Factors were well above the criterion of 0.60 as recommended by Nunally (1978) for assessing reliability of the scale.

\section{Descriptive Statistics}

Among the 141 valid response 26 percent of site engineers and project managers has 12 years of experience, all 141 respondents are belongs to male category. Among 141 response 79.7 percent has been working in a private sectors and 9.5 percent were working in a public sectors. Among 141 response 29.5 percent were involved in commercial building projects, 43.7 percent were involved in residential projects, 19 percent were constructing in industrial projects.

\section{Data Analysis}

Table II: TQM Practices Dimensions

\begin{tabular}{|l|l|l|l|l|}
\hline Factors & $\begin{array}{l}\text { No. of } \\
\text { Variables } \\
\text { Included }\end{array}$ & $\begin{array}{l}\text { Eigen } \\
\text { Value }\end{array}$ & $\begin{array}{l}\text { Percent of } \\
\text { Variance } \\
\text { Explained }\end{array}$ & $\begin{array}{l}\text { Cumulative } \\
\text { Percent of } \\
\text { Variation } \\
\text { Explained }\end{array}$ \\
\hline Organizational Factors & 4 & 6.132 & 11.596 & 11.596 \\
\hline $\begin{array}{l}\text { Communicational } \\
\text { Factors }\end{array}$ & 3 & 2.108 & 9.350 & 20.946 \\
\hline Cultural Factors & 4 & 1.618 & 8.445 & 29.390 \\
\hline $\begin{array}{l}\text { Quality Management } \\
\text { Factors }\end{array}$ & 4 & 1.554 & 6.571 & 35.961 \\
\hline $\begin{array}{l}\text { Customer Satisfaction } \\
\text { Factors }\end{array}$ & 3 & 1.444 & 5.961 & 41.922 \\
\hline $\begin{array}{l}\text { Employee Job Related } \\
\text { Factors }\end{array}$ & 3 & 1.280 & 5.650 & 47.572 \\
\hline $\begin{array}{l}\text { Employee Training } \\
\text { Related Factors }\end{array}$ & 3 & 1.156 & 5.475 & 53.029 \\
\hline $\begin{array}{l}\text { Management } \\
\text { Commitment Factors }\end{array}$ & 4 & 1.046 & 5.320 & 58.349 \\
\hline $\begin{array}{l}\text { KMO Measures of sampling } \\
\text { Adequacy 0.770 }\end{array}$ & $\begin{array}{l}\text { Bartletts test of sphericity: Chi- } \\
\text { Square Value: } 1093.732\end{array}$ \\
\hline
\end{tabular}

Factor 1, which was named as Organizational Factors, was composed of seven items and accounted for 11.596 per cent of the variance. Factor 2, composed of five substances that associated to the Communicational Factors accounted for a supplementary 9.350 percent of the variance. Factor 3, was labeled as Cultural Factors that included five items and it accounted for the additional 8.445 percent of the variance. Factor 4, was the Quality Management Factors that contained three items which accounted for the additional 6.571 per cent of the variance. Factor 5, was interpreted as Customer Satisfaction Factors and comprised two variables, it accounted for an additional 5.961 percent of the variance. Factor 6 was labeled as Employee Job Related Factors; it consisted of two items and accounted for an additional 5.650 percent. Factor 7 and 8 was labeled as Employee Training Related Factors and Management Commitment Factors which consists of two variables each. To study the influence of TQM Practices on Organizational Development, multiple regression was administered. The mean scores of the eight factors obtained from the factor analysis (Organizational Factors, Communicational Factors, Cultural Factors, Quality Management Factors, Customer Satisfaction Factors, Employee Job Related Factors, Employee Training Related Factors, and Management Commitment Factors) represented the independent variables, whereas Organizational Development represented the dependent variable. 
The fitted regression equation is,

where, $\mathrm{Y}=$ mean score on Organizational Development.

$\mathrm{x} 1=$ mean score on Organizational Factors.

$\mathrm{x} 2=$ mean score on Communicational Factors.

$\mathrm{x} 3=$ mean score on Cultural Factors.

x4 =mean score on Quality Management Factors.

$\mathrm{x} 5=$ mean score on Customer Satisfaction Factors.

x6 =mean score on Employee Job Related Factors.

$\mathrm{x} 7=$ mean score on Employee Training Related Factors.

$\mathrm{x} 8=$ mean score on Management Commitment Factors.

a - Alpha.

$\mathrm{e}-$ Error term.

Table III: Influence of TQM Practices on Organizational Development

\begin{tabular}{|c|c|c|c|c|c|}
\hline \multirow{2}{*}{$\begin{array}{l}\text { Independent } \\
\text { Variables }\end{array}$} & \multirow{2}{*}{$\begin{array}{l}\text { Standardized } \\
\text { co- } \text { efficient }\end{array}$} & \multirow{2}{*}{$\begin{array}{l}t \\
\text { value }\end{array}$} & \multirow{2}{*}{$\begin{array}{l}\text { Significanc } \\
e\end{array}$} & \multicolumn{2}{|l|}{ Colinearity } \\
\hline & & & & Tolerance & $V I F$ \\
\hline Constant & .786 & .323 & & 2.432 & .016 \\
\hline $\begin{array}{l}\text { Organizational } \\
\text { Factors }\end{array}$ & .099 & .065 & .121 & 1.528 & .129 \\
\hline $\begin{array}{l}\text { Communicational } \\
\text { Factors }\end{array}$ & .164 & .060 & .211 & 2.742 & .007 \\
\hline
\end{tabular}

Testing of Hypotheses

\begin{tabular}{|l|l|l|}
\hline Hypotheses & Beta & Results \\
\hline Ho1: Organizational Factors will have no significant impact on Organizational Development. & .786 & Supported \\
\hline Ho2: Communicational Factors will have no significant impact on Organizational Development. & .099 & Supported \\
\hline Ho3: Cultural Factors will have no significant impact on Organizational Development. & .164 & Not Supported \\
\hline Ho4: Quality Management Factors will have no significant impact on Organizational Development. & -.001 & Supported \\
\hline Ho5: Customer Satisfaction Factors will have no significant impact on Organizational Development. & .140 & Not Supported \\
\hline Ho6: Employee Job Related Factors will have no significant impact on Organizational Development. & .164 & Supported \\
\hline Ho7: Employee Training Related Factors will have no significant impact on Organizational Development. & .007 & Supported \\
\hline Ho8: Management Commitment Factors will have no significant impact on Organizational Development. & .088 & Supported \\
\hline
\end{tabular}

\section{CONCLUSION}

In this study, eight proportions of TQM practices are emerged. The researcher adopted random sampling method for collecting data from the respondents. This study has been conducted from the period of May 2015 to Jan 2016. This study identified 8 dimensional variables of TQM. These are Organizational Factors, Communicational Factors, Cultural Factors, Quality Management Factors, Customer Satisfaction Factors, Employee Job Related Factors, Employee Training Related Factors, and Management Commitment Factors. To study the influence of TQM Practices on Organizational Development, multiple regression was administered. The mean scores of the eight factors obtained from the factor analysis (Organizational Factors, Communicational Factors, Cultural Factors, Quality Management Factors, Customer Satisfaction Factors, Employee Job Related Factors, Employee Training Related Factors, and Management Commitment Factors) represented the independent variables, whereas Organizational Development represented the dependent variable. Among the dimensions, Cultural Factors and Employee Job Related Factors were regarded as the most

\begin{tabular}{|l|l|l|l|l|l|}
\hline Cultural Factors & -.001 & .067 & .001 & -.017 & .986 \\
\hline $\begin{array}{l}\text { Quality Management } \\
\text { Factors }\end{array}$ & .140 & .054 & .192 & 2.594 & .011 \\
\hline $\begin{array}{l}\text { Customer } \\
\text { Satisfaction Factors }\end{array}$ & .164 & .048 & .266 & 3.426 & .001 \\
\hline $\begin{array}{l}\text { Employee Job } \\
\text { Related Factors }\end{array}$ & .007 & .048 & .010 & .142 & .887 \\
\hline $\begin{array}{l}\text { Employee Training } \\
\text { Related Factors }\end{array}$ & .088 & .049 & .118 & 1.796 & .075 \\
\hline $\begin{array}{l}\text { Management } \\
\text { Commitment Factors } \\
\text { n- siveness }\end{array}$ & .119 & .070 & .127 & 1.704 & .091 \\
\hline R Sauare0.478 & & & & \\
\hline Adiusted R Square0.446 & & & & \\
\hline F-Value & & & & \\
\hline Significance 000
\end{tabular}

The results of regression analysis for the TQM practices are presented in Table III. The results for TQM practices indicated that $\mathrm{R}$ square is equal to 0.478 . This reveals that 47.8 percent of variance in Organizational Development is explained by TQM practices dimensions, $F$ statistics is 15.085 which is significant at the 1 per cent level. The results show that Cultural Factors has a positive impact on Organizational Factors for TQM practices $(\beta=-.001, \mathrm{t}=.067$ $\mathrm{P}<=0.01)$.This was Followed by Employee Job Related Factors $(\beta=.007, t=.048, \mathrm{P}<=0.00)$. The result revealed that there is no significant impact on Ease Cultural Factors, Employee Job Related Factors. important dimensions and it has a positive impact upon Organizational Development. Therefore the construction companies should focus more attention on these factors. Also managers and supervisors are need to be ware of these barriers and try to creating focus on these variables before implementing the TQM practices in their firms. So they can implement the TQM practices very effectively in the Organization.

\section{REFERENCES}

[1] Ali Mohammad Mosadeghrad, "Why TQM programmes fail? A pathology approach", The TQM Journal, Vol. 26, Pp. 160 - 187, 2014.

[2] Andrew W.T. Lau and Tang S.L, "A survey on the advancement of QA (quality assurance) to TQM (total quality management) for construction contractors in Hong Kong", International Journal of Quality \& Reliability Management, Vol.26, Pp.410 - 425, 2009,

[3] Anupam Das and Vinod Kumar and Uma Kumar, "The role of leadership competencies for implementing TQM", International Journal of Quality \& Reliability Management, Vol. 28, Pp. 195 219,2011

[4] Changiz Valmohammadi, "The impact of TQM implementation on the organizational performance of Iranian manufacturing SMEs", The TQM Journal, Vol. 23, Pp. 496 - 509, 2011. 
[5] David Arditi and Murat Gunaydin. H, "Total quality management in the construction process', International Journal of Project Management Vol. 15, Pp. 235-243,1997.

[6] Dinh Thai Hoang, Barbara Igel and Tritos Laosirihongthong, "Total quality management (TQM) strategy and organisational characteristics", Total Quality Management Vol.21,Pp. 931-951, 2010.

[7] Gonza 1ez, T.F. and Guille n, M, "Leadership ethical dimension: a requirement in TQM implementation", The TQM Magazine, Vol.14, Pp.150-64, 2002.

[8] James Harrington .H and Frank Voehl Hal Wiggin, "Applying TQM to the construction industry", The TQM Journal, Vol.24, Pp. 352 - 362, 2012.

[9] Jaideep Motwani, "Critical factors and performance measures of TQM", The TQM Magazine, Vol.13, Pp. 292 - 300, 2001.

[10] Subrahmanya Bhat.K and Jagadeesh Rajashekhar,"An empirical study of barriers to TQM implementation in Indian industries", The TQM Journal, Vol.21,Pp. $261-272,2009$.

[11] Lakhe, R.R. and Mohanty, R.P., "Total quality management: concepts, evolution and acceptability in developing economies", International Journal of Quality \& Reliability Management, Vol.9, pp. 9-33, 1994.

[12] Low Sui Pheng and Jasmine Ann Teo, "Implementing Total Quality Management in Construction Firms", journal of management in engineering, Vol.(20),Pp.8-15, 2004.

[13] Mustafa Maher Altayeb and Mahmoud Bashir Alhasanat, "Implementing total quality management (TQM) in the Palestinian construction industry", International Journal of Quality \& Reliability Management, Vol.31, Pp. 878 -887, 2014.

[14] Nashwan Mohammed Noman Saeed and Awad Sad Hasan, "The effect of total quality management on construction project performance", Journal of Science\& Technology Vol.17, Pp.208-238, 2012.

[15] Ola Ibrahim, "Total Quality management(TQM) and Continuous Improvement as Addressed by Researchers", International Journal of Scientific and Research Publications, Vol.3, Pp. 2250-3153, 2013.

[16] Brah, S.A., Tee, S.L. and Rao B.M., "Relationship between TQM and performance of Singapore companies", International Journal of Quality \& Reliability Management, Vol. 19, No. 4, Pp. 356-379, 2002.

[17] Hansson, J. and Eriksson, H., "The impact of TQM on financial performance", Measuring Business Excellence, Vol. 6, No. 4, Pp. 44-54, 2002.

[18] Hendricks, K.B. and Singhal V.R., "Firm characteristics, total quality management and financial performance", Journal of Operations Management, Vol. 19, No. 3, Pp. 269-285, 2001.

[19] Kaynak H., "The relationship between total quality management and their effects on firm performance", Journal of Operations Management, Vol. 21, No. 4, Pp. 405-435, 2003.

[20] Kenya Institute of Management, "Total Quality Management: Theory, Concepts and Practice", Macmillan Publishers, 2009.

[21] Nunnally J.C., Psychometric theory, McGraw-Hill, New York, NY, 1978.

[22] Perles G.S.M, "The ethical dimension of leadership in the programs of total quality management", Journal of business ethics, Vol. 39, No. 1-2, Pp.59-66,2002.

[23] Prajogo D.I and MC Dermott C.M, "The relationship between TQM practices and organizational culture", International journal of operations and production management, Vol. 25,No. 11, Pp.1101-22, 2005

[24] Raghunathan T.S and SubbaRao S, "A regional study of quality management infrastructure practices in USA and Mexico, International journal of quality and reliability management, Vol.17, No.6, Pp.597-613, 1999.

[25] Ravichandran T, "Swiftness and intensity of administrative innovation adoption: an empirical investigation of TQM in information systems", Decision sciences, Vol. 31, No. 3, Pp.691-729, 2000.

[26] Rich E, "Management fads and information delays: an exploratory simulation study", Journal of business research, Vol. 61, Pp.114357,2008 .

[27] Saraph J.V, Benson P.G and Schroeder R.G, "An instrument for measuring the critical factors of quality management, Decision sciences, Vol. 20, No. 4, Pp.810-29, 1989.

[28] Saraph J.V, Benson P.G and Schroeder R.G, "An instrument for measuring the critical factors of TQM", Decision science,Vol.20, No.4, Pp.810-29, 1989.

[29] Sila Z, "Examining the effects of contextual factors on total quality management performance through the lens of organizational theories: an empirical study", Journal operations management, Vol. 25, No. 1, Pp. 83-109, 2007.

[30] Spencer B.A, "Models of organization and total quality management: a comparison and critical evaluation", Academic of management preview, Vol. 19, No. 3, Pp. 446-71,1994.

[31] Srdoc A, Sluga A and Bratko I, "A quality management model based on the deep quality concept", International journal of quality and reliability management, Vol. 22, No. 3, Pp.278-302,2005.

[32] Subrahmanya Bhat.K and Jagadeesh Rajashekhar, , 'An empirical study of barriers to TQM implementation in Indian industries', The TQM Journal, Vol.21,Pp. 261- 272, 2009.

[33] Sun H, "A comparison of quality management practices in Shanghai and Norwegian companies", International journal of quality and reliability management, Vol.17, No.6, Pp.636-50, 2000.

[34] Tan R.R and Lu Y.G, "On the quality of construction engineering design projects criteria and impacting factors", International journal quality and reliability management, Vol.12, No.5, Pp.18-37, 1995

[35] Thiagarajan T. Zari M and dale B.G, "A proposed model of TQM implementation based on an empirical study of Malaysian industry", International journal of quality and reliability management, Vol. 18, No. 3, Pp. 289-306, 2001

[36] Walton M, "The Deming management method, Pedigree, New York, 1986

[37] Yang C.C, "The impact of human resource management practices on the implementation of TQM", The TQM magazine, Vol. 18, No. 2, Pp. 162$173,2006$.

[38] Yoo D.K, Rao S.S and Hong P, "A comparative study on cultural differences and quality practices: Korea, USA, Mexico and Taiwan", International journal of quality and reliability management, Vol. 23, Pp.607-24, 2006

[39] York K.M and Miree C.E,"Causation or Covariance: an empirical re examination of the link between TQM and financial performance", Journal of operations management, Vol. 22, Pp.291-311,2004.

[40] Zakuan N.M, Yusof S.M, Laosirihongthong T and Shaharoun A.M, "Proposed relationship of TQM and organisational performance using structural equation modelling", Total quality management, Vol. 21, No. 2, Pp. 185-203, 2010.

[41] Zhang Z, "Implementation of total quality management: an empirical study of Chinese manufacturing firms", Unpublished Ph.D thesis, University of Groningen, 2000. 